НАУКОВИЙ ВІСНИК

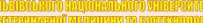

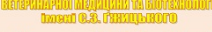

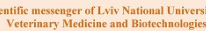

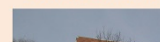
$2+4^{4}$ 11 Minirir

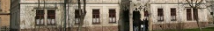
СЕРі: ХАРчОВ технолог ERIIS: Food Том 23 № 96 2021
Науковий вісник Дьвівського національного університету ветеринарної медицини та біотехнодогій імені С.3. Гжицького. Серія: Харчові технології

\section{Scientific Messenger of Lviv National University} of Veterinary Medicine and Biotechnologies.

Series: Food Technologies https://nvlvet.com.ua/index.php/food

UDC 664:637.146.34

\title{
The use of the strain Enterococcus faecium in the technology of yogurt "Carpathian" as an ancillary culture with probiotic properties
}

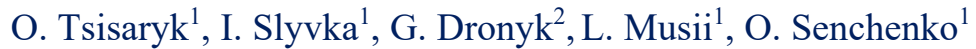

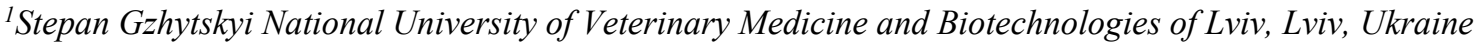 \\ ${ }^{2}$ Bukovinian State Agricultural Research Station of the Institute of Agriculture of Carpathian Region of NAAS, \\ Chernivtsi, Ukraine
}

Article info

Received 17.06.2021

Received in revised form 19.07.2021

Accepted 20.07.2021

Stepan Gzhytskyi National University of Veterinary Medicine and Biotechnologies Lviv, Pekarska Str., 50, Lviv, 79010, Ukraine.

Tel.: + 38-097-986-15-44

E-mail:slyvka.88@ukr.net

Bukovinian State Agricultural Research Station NAAS,

Bogdan Kryzhanivskyi Str., 21 ,

Chernivtsi, 58026, Ukraine.

Tel.: +38-037-252-92-20.
Tsisaryk, O., Slyvka, I., Dronyk, G., Musii, L., \& Senchenko, O. (2021). The use of the strain Enterococcus faecium in the technology of yogurt "Carpathian" as an ancillary culture with probiotic properties. Scientific Messenger of Lviv National University of Veterinary Medicine and Biotechnologies. Series: Food Technologies, 23(96), 93-101. doi: 10.32718/nvlvet-f9616

The results of research on the technological features of the production of yogurt "Carpathian" are covered in the article. The bacterial preparation of Chr. Hansen series YoFlex Premium 1.0 (L. bulgaricus, S. thermophilus) and Creamy 1.0 (L. bulgaricus, S. thermophilus, L. rhamnosus) and strain E. faecium SB 18, which is isolated from traditional Carpathian fermented products were used to produce research yogurt samples. It was found that when the strains were used together, the microorganisms were compatible, did not show interspecific antagonism and did not inhibit the enzymatic process. Based on yogurt microorganisms and E. faecium SB 18 strain, seven prototypes of yogurt were created: № 1 (100\%) - control, Premium + Creamy; № 2 (100\%) - control, pure culture of E. faecium SB 18; №3 (100:100\%) - control, (Premium + Creamy $)+$ E. faecium $S B$ 18; №4 (50:50\%) - (Premium + Creamy) + Ent. faecium SB 18; № 5 $(70: 30 \%)-($ Premium + Creamy $)+$ Ent. faecium SB 18; № $6(80: 20 \%)-($ Premium + Creamy $)+$ Ent. faecium SB 18; № 7 (90:10\%) - (Premium + Creamy) + Ent. faecium SB 18. The fastest fermentation took place in sample № 1 ( $p H 4.78$ units - 4h), the slowest in sample №2 ( $\mathrm{pH} 4.81$ units $-6 \mathrm{~h}$ ), where only pure culture of E. faecium $S B 18$ was used. The fermentation time in sample №3 was initially slower and then more active ( $p H 4.77$ units - 4h). The acidity increased more moderately in samples № 4, 5, 6, 7 for 4 h, and at the end of fermentation was 4.84 units, 4.76 units, 4.81 units. and 4.75 units. in accordance. According to organoleptic evaluation, the experimental samples were characterized by slight differences. In general, it is noted that the addition of microbial culture of E. faecium SB 18 improves the taste of yogurt. Samples № 6 and № 7 with the addition of E. faecium SB 18 strain in the amount of 20 and $10 \%$ were noted for the best organoleptic properties. According to the score scale, the above-mentioned samples received the highest number of points -48 , out of a possible 50. The dependence of the acidity of yogurt during storage was established on the dose and composition of the bacterial preparation. It was investigated that the acidity of yogurt, which contained an additional strain of E. faecium SB 18 in the ratios of 100:100 (sample 3) and 50:50 (sample 4), tends to increase rapidly in acidity, which is associated with increased lactic acid bacteria. It was found that partial replacement of the amount of traditional yogurt leaven in the ratio of 70:30 (sample 5), 80:20 (sample 6) and 90:10 (sample 7) provides the optimal course of the enzymatic process during fermentation and storage. It was found that the use of traditional yogurt leaven YoFlex Premium 1.0 and Creamy 1.0. together with strain E. faecium SB 18 in a ratio of 80:20, provides excellent consumer properties of the product.

Key words: lactic acid bacteria, technology, probiotics, fermentation, yogurt.

\section{Технологія йогурту “Карпатський” із використанням штаму Enterococcus faecium, як допоміжної культури 3 пробіотичними властивостями}

\author{
О. Цісарик ${ }^{1}$, І. Сливка ${ }^{1}$, Г. Дроник ${ }^{2}$ Л. Мусій ${ }^{1}$, О. Сенченко ${ }^{1}$
}


${ }^{1}$ Львівський національний університет ветеринарної медицини та біотехнологій імені С. 3. Гжицького, Львів, Україна

${ }^{2}$ Буковинська державна сільськогосподарська дослідна станиія Інституту сільського господарства Карпатського регіону Наџіональної академії аграрних наук України, м. Чернівиі, Україна

У статті висвітлені результати досліджень технологічних особливостей виробничтва йогурту “Карпатський”. У ролі основної закваски використовували традиційні йогуртові культури фірми Chr. Hansen серії YoFlex Premium 1.0 (L. bulgaricus, S. thermophilus) ma Creamy 1.0 (L. bulgaricus, S. thermophilus, L. rhamnosus) та додатковий штам E. fаесіит SB 18, який виділений $з$ традиційних карпатських ферментованих продуктів. Встановлено, що за умови спільного використання штамів, м/о були сумісні, не проявляли міжвидового антагонізму і не гальмували перебіг ферментативного прочесу. На основі класичної закваски та штаму E. fаесіит SB 18 створили сім дослідних зразків йогурту: № 1 (100 \%) - контроль, Рrетіuт+Сгеату; № 2 (100\%) - контроль, чиста культура E. faecium SB 18; № 3 (100:100 \%) - контроль, (Premium+Creamy) + E. faеcium SB 18; № 4 (50:50 \%) $($ Premium +Creamy) + Ent. faecium SB 18; № 5 (70:30 \%) - (Premium+Creamy) + Ent. faecium SB 18; № 6 (80:20\%) (Premium+Creamy) + Ent. faecium SB 18; № 7 (90:10\%) - (Premium+Creamy) + Ent. faесіит SB 18. Найшвидме ферментаиія відбувалась у зразку № 1 (рH 4,78 од. - 4 год), найповільніше у зразку № 2 (рH 4,81 од. - 6 год), де використовували лише чисту культуру E. faесіит SB 18. У зразку № 3 час сквашування спершу тривав повільніше, а потім активніше (рH 4,77 од. - 4 год). $У$ зразках № 4, 5, 6, 7 кислотність наростала більш помірно протягом 4 год, і на кінець сквашування становила 4,84 од., 4,76 од., 4,81 од. та 4,75 од. відповідно. Згідно органолептичної очінки, дослідні зразки характеризувались незначними відмінностями. В загальному відзначено, що додавання мікробіальної культури E. fаесіит SB 18 сприяє підвищенню смакових властивостей йогурту. Найкращими органолептичними властивостями відзначалися зразки № 6 i № 7 із додаванням штаму E. faесіит SB 18 у кількості 20 i $10 \%$. $3 a$ бальною шкалою вищезгадані зразки отримали найвищу кількість балів - 48, із можливих 50. Встановлено залежність кислотності йогурту під час зберігання від дози та складу бактеріального препарату. Досліджено, що кислотність дослідних зразків йогуртів, що містять у свосму складі додаткову мікробіальну культуру Е. fаесіит SB 18 у співвіднотеннях 100:100 (зразок 3) та 50:50 (зразок 4), мають тенденцію до швидиого наростання кислотності, що, ймовірно, пов'язане зі збільшенням кількості молочнокислих бактерій. А часткова заміна кількості традииійної йогуртової закваски у співвіднотзеннях 70:30 (зразок 5), 80:20 (зразок 6) та 90:10 (зразок 7) забезпечує оптимальний перебіг ферментативного прочесу під час сквамування та в процесі зберігання. Провівши дослідження біотехнологічних прочесів, що відбуваються під час виробництва йогурту із різним складом молочнокислих бактерій, визначено, щео використання традиџійної йогуртової закваски YoFlex Premium 1.0 та Сreaтy 1.0. разом із штамом E. fаесіит SB 18 у співвідношенні 80:20, забезпечує відмінні споживні властивості продукту.

Ключові слова: молочнокислі бактерії, технологія, пробіотики, ферментація, йогурт.

\section{Ветуп}

В Україні для виробництва ферментованих молочних продуктів, в тому числі і йогуртів, здебільшого використовують імпортні заквашувальні препарати, які характеризуються різним складом мікробіальних культур. Натомість немає бактеріального препарату, у склад якого включені типові штами молочнокислих бактерій, які виділені з традиційних карпатських ферментованих молочних продуктів. При цьому, склад таких препаратів був би найбільш наближеним до природного складу культур молочних бактерій, домінуючих у сирому молоці.

Класично йогурт виготовляють 3 молока, шляхом сквашування термофільним стрептококом і болгарською паличкою (Streptococcus thermophilus i Lactobacillus bulgaricus) 3 можливим додатковим використанням інших культур.

Головна роль стартових культур молочнокислих бактерій, полягає у продукуванні молочної кислоти та служить рушійною силою для процесу протеолізу, які $\epsilon$ необхідними для розвитку унікального аромату ферментованого молочного продукту та формування його специфічних сенсорних властивостей (McSweeney, 2004).

Молочна компанія "Галичина" розширила лінію смаків йогуртно-кефірної продукції та оновила дизайн. У межах ребрендингу випустили новинку карпатський йогурт, виготовлений за особливою технологією і рецептурою.

Ключовий меседж, 3 яким оновилася компанія, це чистота: "Галичина" із чистих Карпат, чистомолочний продукт та чиста краса, тобто природність і натуральність. Дизайн упаковки втілив концепцію “чистоти" - від колористики до вибору техніки, чим підкреслив місце походження, автентичність рецептур та чистоту сировини.

"Первозданність карпатської природи" та багаті кисломолочні традиції мешканців Карпат надихнули технологів створити карпатський йогурт. Це натуральний продукт без цукру та зайвих доданків. Він має чистий вершковий смак, натуральний (має природну жирність) та корисний (завдяки високому вмісту білку).

У технології карпатського йогурту МК “Галичина" використовує заквашувальні культури імпортного виробництва. Для надання продукту функціональних властивостей та підтвердження продукту слоганом "Бери силу Карпат" ми пропонуємо використовувати культуру Enterococcus faecium SB 18, яка виділена в Україні із карпатської бринзи.

Різні штами молочнокислих бактерій, включаючи непатогенні ентерококи, тривалий час використовують в складі бактеріальних препаратів для виробництва ферментованих молочних продуктів та пробіотиків (Franz, 2011). Штами виду Enterococcus faecium мають широке застосування у виробництві сирів, ферментованих молочних продуктів та безпечні для використання у медичних та ветеринарних цілях (Ljungh \& Wadstrom, 2006). Вони визнані, як безпечні (GRAS) організми для людини, оскільки вони не відносяться до патогенної та умовно-патогенної мікрофлори (Behnsen et al., 2013).

E. faecium становлять досить велику частину від загальної кількості мікроорганізмів, виділених із домашніх ферментованих молочних продуктів. При аналізі мікрофлори різних національних продуктів, особливо сирів, в країнах 3 найбільш розвиненими 
традиціями сироваріння у Франції та Італії, поряд 3 іншими бактеріями, часто виявляються ентерококи (Andrighetto et al., 2006). Причому, з національних сирів в більшій кількості ізолюють не мезофільні, а термофільні коки, в основному Streptococcus thermophilus, Streptococcus macedonicus, Enterococcus. ssp. Найпоширенішими у відсотковому відношенні видами ентерококів, виділеними 3 кисломолочних продуктів, є види E. faecium, E. faecalis i E. durans.

Ентерококи відіграють важливу роль в процесі виробництва кисломолочних продуктів. Їх відносять до нестартових культур молочнокислих бактерій "nonstarter lactic acid bacteria" (NSLAB), які ідентифiковані при виготовленні різноманітних кисломолочних продуктів з сирого або пастеризованого молока, в основному на півдні Європи. Для прикладу, чисельність ентерококів в сирі типу "Медітеріан" може коливатись в діапазоні від $10^{4}$ до $10^{6} \mathrm{KУО/г,} \mathrm{а} \mathrm{в} \mathrm{повніс-}$ тю дозрілому сирі від $10^{5}$ до $10^{7}$ КУО/г. Таким чином, використання ентерококів при виготовленні національних кисломолочних продуктів, може бути обгрунтовано їх важливими технологічними і біологічними властивостями, що дасть можливість отримати продукт із заданими технологічними та смаковими характеристиками.

Авторами (Marshall, 2005; Ljungh \& Wadstrom, 2006; Behnsen et al., 2013) повідомляється, що ентерококи продукують низькомолекулярні білки, які називаються бактеріоцинами. Ці бактеріоцини проявляють антибактеріальну активність та пригнічують ріст та розвиток патогенних мікроорганізмів, які викликають псуваня продуктів харчування. Використання бактеріоцинів підвищує безпеку харчових продуктів та подовжує їх термін придатності (Marshall, 2005).

Ентерококи, які володіють хорошими технологічними властивостями і виділені з ферментованих молочних продуктів кустарного виробництва, зустрічаються нечасто і складають лише 3,6-11,6 \% (Serio et al., 2010; Câmara et al., 2019). Авторами Andrighetto C., Durlu-Ozkaya F., Sarantinopoulos Р. повідомляється, що ізольовані ентерококи з продуктів непромислового виробництва, характеризуються низькою кислотоутворювальною здатністю, але невеликий відсоток ізолятів здатні виробляти кислоту, достатню для того, щоб $\mathrm{pH}$ знижувалось нижче 5,0-5,2 після інкубації протягом 16-24 год при $37^{\circ} \mathrm{C}$.

Через низьку здатність до кислотоутворення та обмежені протеолітичні властивості, ентерококи доволі рідко розглядають, як основну культуру у складі бактеріального препарату (Giraffa, 2003), однак їх використовують як допоміжні (Fortina et al., 2008) або як захисні культури (Perin et al., 2016).

Отже, крім впливу на формування сенсорних властивостей, ентерококи відіграють важливу роль в процесах розщеплення білків молока та накопичення біоактивних пептидів 3 потенційною користю для здоров'я споживачів (García-Solache \& Rice, 2019).

Молочні білки є найбільшим джерелом пептидів, які мають антигіпертензивну, гіпохолестеринемічну, антигіперглікемічну, імуномодулюючу, протимікробну та антиоксидантну активність. В зв'язку із високою протеолітичною активністю деякі молочнокислі бак- терії, в тому числі ентерококи, при культивуванні їх в молоці виробляють біоактивні пептиди (Graham et al., 2020). Виробництво антигіпертензивних пептидів ентерококами при бродінні молока було досліджено як in vitro (Regazzo et al., 2010; Gútiez et al., 2014; Graham et al., 2020), так i на тваринних моделях (Muguerza et al., 2006; Quirós et al., 2007).

Дослідження (Muguerza et al., 2006) на мишах in vivo продемонстрували, що пробіотичний штам E. faecium проявляє антигіперглікемічний ефект та зменшує інсулінорезистентність при одночасному прийомі з їжею.

Автори (Regazzo et al., 2010) використовували у технології фементованого молока культури Enterococcus faecalis TH563 та Lactobacillus delbrueckii subsp. bulgaricus LA2, 3 метою вивчення імуномодулюючих та антигіпертензивних властивостей. Встановлено вищу протеолітичну активність та інгібуючу активність АПФ (інгібітори ангіотензинперетворюючого ферменту) при використанні штаму E. faecalis TH563 для ферментації молока.

Ентерококи є одними із мікроорганізмів, які використовуються в харчовій біотехнології, як продуценти кон'югованої лінолевої кислоти (CLA) та іiі похідної альфа-ліноленової та арахідонової кислот, до яких прикута значна увагу через потенційний вплив на здоров'я людини (Andrade et al., 2012). Дослідженнями (Kishino et al., 2002) у лабораторних умовах продемонстровано, що штами ентерококів можуть продукувати високі концентрації цієї поліненасиченої жирної кислоти.

Використання ентерококів у технології йогурту забезпечує не лише згортання молока, але й впливає на формування смаку, аромату та консистенції продукту (Ozen \& Dinleyici, 2015).

Позитивну роль ентерококів у технології йогурту відзначили автори (Hadji-Sfaxi et al., 2018; Akpinar et al., 2020), використовуючи поєднання двох штамів $E$. faecium та E. durans, як допоміжних культур у виробництві пробіотичного йогурту. Вони відзначали значні зміни та відмінності в активній, титрованій кислотності, консистенції та мікробіологічних властивостях продукту, що містив допоміжні культури ентерококів, протягом періоду зберігання $(\mathrm{P}<0,05)$, тоді як значних відмінностей між сенсорними властивостями не було (Р > 0,05). Позитивний вплив відзначено на функціональні властивості продукту шляхом збільшення вмісту життєздатних клітин пробіотичних бактерій.

Ентерококи, практично не використовують у технології ферментованих молочних продуктів в Україні, хоча йогурт - це найпоширеніший ферментований харчовий продукт, який часто споживають жителі нашої та інших країн.

Традиційно, в Україні вид E. faecium використовують в технології кисломолочного продукту Геролакт. Технологію виробництва Геролакту було розроблено у 1984 році вітчизняними науковцями Інституту продовольчих ресурсів, Інституту геронтології, Інституту мікробіології і вірусології із застосуванням спеціального бактеріального концентрату на основі традиційних молочнокислих бактерій та культури 
E. faecium, характерної для довгожителів Абхазії (Roanchyk et al., 2015).

Сьогодні молочнокислі бактерії родини Lactobacteriaceae (роди Leuconostoc, Lactococcus, Lactobacterium і Enterococcus) є основою більшості заквашувальних препаратів, які використовуються для виробництва різних кисломолочних продуктів. Тому актуальним підходом для пошуку нових штамів молочнокислих мікроорганізмів, перспективних у ролі заквашувальних препаратів і пробіотиків, є вивчення видового складу мікрофлори традиційних кисломолочних продуктів, виділення із них молочнокислих культур і вивчення їх властивостей (Behnsen et al., 2013).

Мета і завдання дослідження. Метою нашої роботи було розробити технологію йогурту "Карпатський" iз використанням додаткового штаму E. faecium SB 18 в поєднанні із основною закваскою Chr. Hansen cepiï YoFlex Premium 1.0 (L. bulgaricus, S. thermophilus) та Creamy $1.0 \quad$ (L. bulgaricus, $S$. thermophilus, L. rhamnosus).

Експериментальні дослідження органолептичних, фізико-хімічних та мікробіологічних показників зразків йогурту проводилися у лабораторії кафедри технології молока i молочних продуктів Львівського національного університету ветеринарної медицини та біотехнологій імені С. З. Гжицького та лабораторії ТОВ МК “Галичина".

Метою першого етапу дослідної роботи було підібрати дозу бактеріального препарату основної йогуртової закваски Premium 1.0 і Creamy 1.0 та допоміжної чистої культури $E$. faecium SB 18 , використовуючи різні їх співвідношення.

Для дослідження було виготовлено 7 зразків йогурту $з$ м.ч.ж. 2,5\%:

зразок $1(100 \%)$ - контроль, класична йогуртова закваска (Premium+Creamy);

зразок $2(100 \%)$ - контроль, чиста культура

E. faecium SB 18;

зразок 3 (100:100\%) - контроль, закваска

(Premium+Creamy) + E. faecium SB 18;

зразок $4(50: 50 \%)$ - закваска (Premium+Creamy) + Ent. faecium SB 18;

зразок 5 (70:30\%) - закваска (Premium+Creamy) + Ent. faecium SB 18;

зразок $6(80: 20 \%)$ - закваска (Premium+Creamy) + Ent. faecium SB 18;

зразок 7 (90:10\%) - закваска (Premium+Creamy) + Ent. faecium SB 18.

Заквашувалні препарати серії YoFlex Premium 1.0 та Creamy 1.0 вносили у замороженому вигляді, чисті культури E. faecium SB 18 у ліофілізованому стані, попередньо активовані стерильним знежиреним молоком.

Доза заквашувального препарату (100\%) Premium 1.0 становила $500 \mathrm{U}$ на 5 т молока та $250 \mathrm{U}$ для Creamy 1.0. Доза чистої культури E. faecium SB 18 $(100 \%)$ становила $10^{11}$ КУО/г на 1 т молока.

Йогурт виготовляли резервуарним способом. Основною сировиною для виготовлення йогурту “Карпатський” $\epsilon$ коров'яче молоко з карпатських фермерських господарств. Молочну нормалізовану сировину для виготовлення йогурту отримали від МК “Галичина”. Йогурт виготовляли 3 масовою часткою жиру 2,5 \%. Нормалізовану суміш направляли на пастеризацію при температурі $(95 \pm 1){ }^{\circ} \mathrm{C}$ з витримкою 5 хв. Після пастеризації нормалізовану суміш охолоджували. В охолоджену до температури $(40 \pm 1){ }^{\circ} \mathrm{C}$ суміш вносили бактеріальні препарати прямого внесення cepiï YoFlex Premium 1.0, Creamy 1.0 та E. faecium SB 18 у різних співвідношеннях у вищезазначених дозах. Для рівномірного розподілення культури застосовували перемішування протягом 10-15 хв. Після внесення культури суміш піддавали ферментації за температури $(40 \pm 1){ }^{\circ} \mathrm{C}$. Протягом сквашування контролювали наростання титрованої та активної кислотності. Титровану кислотність визначали за ГОСТ 3624-92 “Молоко і молочні продукти. Титрометричні методи визначення кислотності”. Вимірювання активної кислотності проводили за допомогою електронного pH-метра "Muttler Toledo MP220". Суміш сквашували до досягнення активної кислотності 4,80 од. $\mathrm{pH}$ або $70^{\circ} \mathrm{T}$. Тривалість сквашування 4 год. Титрована кислотність в кінці сквашування $76^{\circ} \mathrm{T}$.

Готовий продукт аналізували на відповідність вимогам діючого ДСТУ 4343:2004. “Йогурти. Загальні технічні умови”.

Мікробіологічні показники продукту досліджували згідно ДСТУ IDF 117В:2003 “Йогурт. Визначення кількості характерних мікроорганізмів. Метод підрахунку колоній за температури $37^{\circ} \mathrm{C}$ '. Пробу об'ємом 1 мл змішували з 9 мл дистильованої води перемішували до отримання однорідної емульсії, з якої готували десятикратні розведення. Загальну кількість молочнокислих культур визначали паралельним посівом розведень зразків йогурту у чашки Петрі на середовище Лактобакагар 3 наступним інкубуванням у термостаті за температури $(37 \pm 1){ }^{\circ} \mathrm{C}$ протягом 3 днів в анаеробних умовах. Визначення кількості дріжджів та плісені визначали посівом на середовище Сабуро (ГОСТ 10444.12-88).

\section{Результати та їх обговорення}

В технології йогурту “Карпатський” вперше використано культури молочнокислих бактерій, зокрема штаму E.faecium SB 18 виділеного із традиційних карпатських продуктів. В основному, заквашувальні препарати, які сьогодні використовує вітчизняна молочна промисловість, не відображають типову мікрофлору традиційних ферментованих молочних продуктів, що безпосередньо бере участь у формуванні специфічних органолептичних та функціональних властивостей продукту.

Штам E. faecium SB 18 виділений із традиційної карпатської бринзи, яка виготовляється із сирого овечого молока у високогір'ї Карпат. Культура E. faecium SB 18 ідентифікована на молекулярно генетичному рівні (секвеновано ген 16S рРНК) та внесена в міжнародну генетичну базу даних GenBank, оскільки є абсолютно новою мікробіальною культурою. Реєстраційний номер послідовностей гену $16 \mathrm{~S}$ рРНК в GenBank: MZ227257 (Slyvka et al., 2018). 
Проведено депонування штаму E. faecium SB 18 (реєстраційний № 796) в Депозитарій Державного науково-контрольного інституту біотехнології і штамів мікроорганізмів 3 метою використання його в промисловості, як штам, що входить в склад бактеріального препарату для виробництва ферментованих молочних продуктів.

Штам E. faecium SB 18 попередньо вивчений щодо можливості проявляти цінні пробітичні властивості. Встановлено, що мікроорганізм здатний підвищувати кислотність середовища культивування за різних температурних режимів та проявляє антагоністичну активність щодо патогенних та умовно-патогенних мікроорганізмів (Kushnir et al., 2020). Щодо синтезу біологічно активних речовин, досліджено, що $E$. faecium SB 18 здатний синтезувати як замінні (серин, гліцин) так і незамінні (лізин, гістидин, треонін) амінокислоти, а також вітаміни групи В (Kushnir et al., 2020).

Традиційною технологією виготовлення йогурту у промислових умовах є додавання бактеріальної закваски у пастеризоване молоко, що сприяє ферментації і утворенню згустку. Саме мікрофлора заквашувальних культур визначає специфічні фізико-хімічні, органолептичні властивості, забезпечує безпеку споживання та збереження якісних характеристик впродовж зберігання. Завдяки мікрофлорі можна контролювати біохімічні та ферментативні процеси під час ферментації молочної основи та спрямувати їх у бажаному напрямі (Didukh, 2008).

При встановленні дози заквашувального препарату намагались зберегти відповідні для йогурту органолептичні властивості та необхідні фізико-хімічні і структурно-механічні властивості продукту.

За контроль було обрано зразки 1, 2 і 3, оскільки використовували окремо класичну йогуртову закваску cepiï YoFlex Premium 1.0 + Creamy 1.0 та чисту ліофілізовану культуру E. faecium SB 18 . У зразку 3 використали поєднання YoFlex Premium 1.0 + Creamy 1.0 та E. faecium SB 18, як 100:100\%. Таке поєднання заквашувальних препаратів дасть можливість оцінити зміни від зменшення або збільшення заквашувального препарату у процесі виготовлення і зберігання продукту. Для дослідних зразків йогурту заквашувальний препарат YoFlex Premium 1.0 + Creamy 1.0 становив 50, 70,80 і 90 \%, відповідно E. faecium SB 18 - 50, 30, 20 i $10 \%$.

Важливим етапом при виробництві ферментованих молочних продуктів $є$ контроль над процесами зміни показників титрованої та активної кислотності в процесі ферментації.

Дослідження показників активної кислотності йогурту під час ферментації наведено на рис.1.

При виробництві йогурту із різним співвідношенням культур молочнокислих бактерій спостерігали різну інтенсивність і швидкість ферментативного процесу.

Найшвидше ферментація відбувалась у контрольному зразку 1 , протягом 4 год. Найповільніше спостерігали зміни кислотності у контрольному зразку 2, де використовували лише чисту культуру E. faecium SB 18 . Час сквашування тривав 6 год. Триваліший процес сквашування пов'язуємо iз формою внесення заквашувального препарату, оскільки у ліофілізованому стані мікробіальна культура активується довше. У контрольному зразку 3 час сквашування спершу тривав повільніше, а потім активніше. У дослідних зразках 4, 5, 6, 7 кислотність наростала більш помірно, час сквашування молочної суміші тривав 4 год. відповідно, як у контрольному зразку 1 та 3.

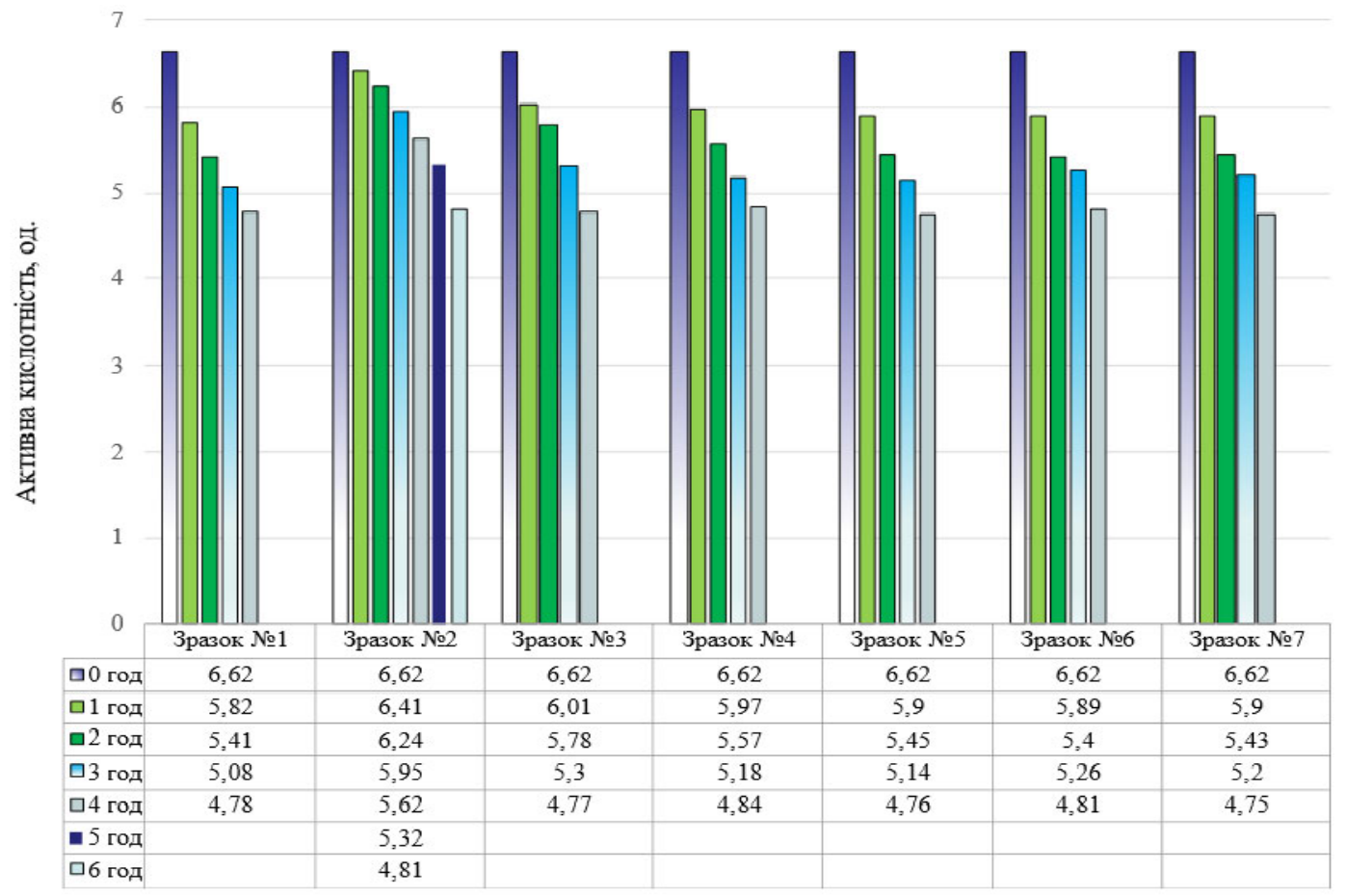

Рис. 1. Зміна показників активної кислотності під час ферментації 
Як результат, встановлено, що використання допоміжної культури E. faecium SB 18 не гальмує процесу сквашування молочної суміші та проявляється синергізм із культурами молочнокислих бактерій, які включені в склад заквашувального препарату YoFlex Premium 1.0 та Creamy 1.0.

Охолоджений до температури $(4 \pm 2){ }^{\circ} \mathrm{C}$ йогурт аналізували за органолептичними властивостями, результати аналізу наведено у таблиці 1.

Таблиця 1

Органолептичні властивості йогурту та його бальна оцінка

\begin{tabular}{|c|c|c|c|c|c|}
\hline $\begin{array}{l}\text { Дослідні } \\
\text { зразки }\end{array}$ & $\begin{array}{c}\text { К-сть балів } \\
(\text { макс. 50) }\end{array}$ & $\begin{array}{l}\text { Зовнішній вигляд та консистенція } \\
\text { (макс. 25) }\end{array}$ & $\begin{array}{l}\text { К-сть } \\
\text { балів }\end{array}$ & $\begin{array}{c}\text { Смак і запах } \\
\text { (макс. 25) }\end{array}$ & $\begin{array}{l}\text { К-сть } \\
\text { балів }\end{array}$ \\
\hline Зразок 1 & 46 & $\begin{array}{c}\text { Однорідна, ніжна, в'язка } \\
\text { консистенція, без газоутворення. } \\
\text { Колір білий }\end{array}$ & 23 & $\begin{array}{l}\text { Чистий, кисломолочний, } \\
\text { вершковий, без сторонніх } \\
\text { присмаків і запахів }\end{array}$ & 23 \\
\hline Зразок 2 & 46 & $\begin{array}{l}\text { згусток однорідний, в міру щільний, } \\
\text { без вираженої в’язкості. Колір білий }\end{array}$ & 22 & $\begin{array}{c}\text { Чистий, виражений } \\
\text { кисломолочний, без сторонніх } \\
\text { присмаків і запахів }\end{array}$ & 24 \\
\hline Зразок 3 & 46 & $\begin{array}{c}\text { згусток однорідний, в міру щільний, } \\
\text { менш в'язкий, без газоутворення. } \\
\text { Колір білий }\end{array}$ & 23 & $\begin{array}{c}\text { Чистий, виражений } \\
\text { кисломолочний, вершковий, без } \\
\text { сторонніх присмаків і запахів }\end{array}$ & 23 \\
\hline Зразок 4 & 46 & $\begin{array}{l}\text { згусток однорідний, в міру щільний, } \\
\text { без газоутворення. Колір білий }\end{array}$ & 23 & $\begin{array}{l}\text { Чистий, виражений } \\
\text { кисломолочний, вершковий, без } \\
\text { сторонніх присмаків і запахів. }\end{array}$ & 23 \\
\hline Зразок 5 & 46 & $\begin{array}{l}\text { згусток однорідний, в міру щільний, } \\
\text { без газоутворення. Колір білий }\end{array}$ & 23 & $\begin{array}{c}\text { Чистий, виражений } \\
\text { кисломолочний, вершковий, без } \\
\text { сторонніх присмаків і запахів. }\end{array}$ & 23 \\
\hline Зразок 6 & 48 & $\begin{array}{l}\text { згусток однорідний, в міру щільний, } \\
\text { без газоутворення. Колір білий }\end{array}$ & 24 & $\begin{array}{c}\text { Чистий, виражений } \\
\text { кисломолочний, вершковий, без } \\
\text { сторонніх присмаків і запахів. }\end{array}$ & 24 \\
\hline Зразок 7 & 48 & $\begin{array}{c}\text { згусток однорідний, в міру щільний, } \\
\text { в'язкий, без газоутворення. Колір } \\
\text { білий }\end{array}$ & 24 & $\begin{array}{l}\text { Чистий, кисломолочний, } \\
\text { вершковий, без сторонніх } \\
\text { присмаків і запахів }\end{array}$ & 24 \\
\hline
\end{tabular}

Згідно органолептичної оцінки, дослідні зразки йогурту виготовлені із різним співвідношенням бактеріальних культур характеризувались незначними відмінностями. В загальному відзначено, що додавання мікробіальної культури E. faecium SB 18 сприяє підвищенню смакових властивостей йогурту.

Зразки 6 i 7 із додаванням E. faecium SB 18 у кількості 20 і 10 \%, відзначалися найкращими органолептичними властивостями. Консистенція згустків була однорідна, в міру щільна, без газоутворення, смак i запах - чистий, виражений кисломолочний, вершковий, без сторонніх присмаків i запахів. За бальною шкалою вищезгадані зразки отримали найвищу кількість балів - 48, із можливих 50.

У дослідному зразку 2 із додаванням лише мікробіальної культури E. faecium SB 18, відзначали відмінності у характері згустку. Він характеризувався більш щільною та рихлою консистенцію в порівнянні із рештою зразків йогурту. Очевидним $є$ факт впливу властивостей мікробіальних культур на формування i щільність згустку.

Решта дослідних зразків йогурту, отримала однакову загальну кількість балів - по 46, із можливих 50, оскільки всі характеризувались подібними органолептичними властивостями.

В процесі зберігання йогурту було встановлено терміни його зберігання за зниженням активної кислотності та наростанням титрованої кислотності. Дослідження проводили на 1, 7, 14 та 21 добу зберігання йогурту.
Динаміку зміни титрованої кислотності йогурту в процесі зберігання представлено на рис. 2. Результати зниження активної кислотності наведені в таблиці 2.

Йогурти, виготовлені 3 різним співвідношенням мікробіальних культур набувають нових фізикохімічних показників.

Встановлено, що у йогурті, виготовленому iз традиційною йогуртовою закваскою та із додаванням мікробіальної культури E.faecium SB 18 у співвідношенні 100:100 (зразок №3) наростання титрованої кислотності під час зберігання відбувалося найактивніше. Титрована кислотність на 21 добу зберігання досягала позначки $162^{\circ} \mathrm{T}$ ( $\mathrm{pH}-3,81$ од.), що корелює із швидкістю наростання кислотності під час сквашування.

У зразках 1, 2 та 4 також відзначено активніший перебіг ферментативного процесу під час зберігання йогурту. Титрована кислотність досягала позначки на 21 добу зберігання у зразку $1-142{ }^{\circ} \mathrm{T}$ ( $\mathrm{pH} 3,99-4,0$ од.), у зразку $2-154^{\circ} \mathrm{T}$ (рН 3,90 од.) та у зразку $4-$ $146^{\circ} \mathrm{T}$ (pH 3,95 од.). У зразках 5, 6, 7, де замінено кількість основної йогуртової закваски на мікробіальну культуру E. faecium SB 18 у менших співвідношеннях, зміни титрованої кислотності відбувалися помірніше. На 21 добу зберігання титрована кислотність у зразку 5 становила $138^{\circ} \mathrm{T}$ (pH 4,03 од.), у зразку $6-126^{\circ} \mathrm{T}$ (рН 4,12 од.) та у зразку $7-124^{\circ} \mathrm{T}$ (рН 4,18 од.). 


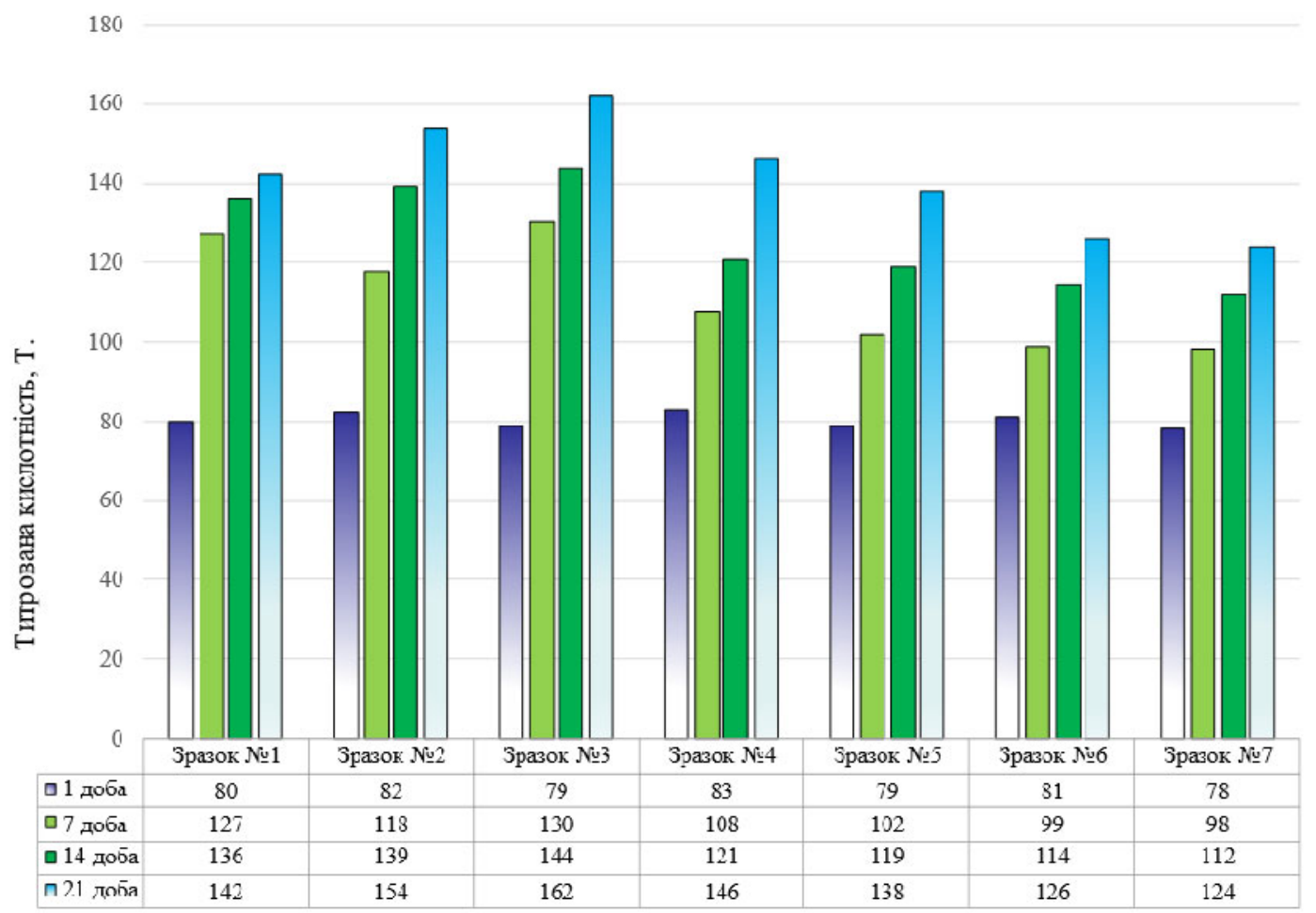

Рис. 2. Динаміка зміни титрованої кислотності йогурту під час зберігання

Згідно 3 ДСТУ 4343:2004. “Йогурти. Загальні технічні умови” показники титрованої кислотності мають бути в межах $80-140^{\circ} \mathrm{T}$ та активної 4,8-4,0 од. $\mathrm{pH}$. Тому за результатами динаміки зміни показників титрованої та активної кислотності встановлено наступні терміни зберігання зразків йогурту за температури $4 \pm 2{ }^{\circ} \mathrm{C}$ : зразок $1-21$ доба; зразок $2,3,4$ - 14 діб; зразки 5, 6 і 7 - 21 доба.

Таблиця 2

Показники активної кислотності під час зберігання

\begin{tabular}{ccccc}
\hline \multirow{2}{*}{ Дослідні зразки } & \multicolumn{4}{c}{ Активна кислотність йогурту під час зберігання, од. $\mathrm{pH}$} \\
\cline { 2 - 5 } & 1 доба & 7 доба & 14 доба & 21 доба \\
\hline Зразок 1 & 4,78 & 4,18 & 4,03 & 3,99 \\
Зразок 2 & 4,81 & 4,23 & 4,12 & 3,90 \\
Зразок 3 & 4,77 & 4,11 & 3,98 & 3,95 \\
Зразок 4 & 4,84 & 4,29 & 4,12 & 4,03 \\
Зразок 5 & 4,76 & 4,34 & 4,13 & 4,12 \\
Зразок 6 & 4,81 & 4,39 & 4,15 & 4,18 \\
Зразок 7 & 4,75 & 4,41 & 4,19 & \\
\hline
\end{tabular}

Встановлено залежність кислотності йогурту від дози та складу бактеріального препарату. Досліджено, що кислотність дослідних зразків йогуртів, що містять у своєму складі додаткову мікробіальну культуру E. faecium SB 18 у співвідношеннях 100:100 (зразок 3) та 50:50 (зразок 4), мають тенденцію до швидшого наростання кислотності, що, ймовірно, пов'язане зі збільшенням кількості молочнокислих бактерій. А часткова заміна кількості традиційної йогуртової закваски у співвідношеннях 70:30 (зразок 5), 80:20 (зразок 6) та 90:10 (зразок 7) забезпечує оптимальний перебіг ферментативного процесу під час сквашування та в процесі зберігання.

Йогурти при зберіганні піддаються змінам, які залежать від умов виготовлення та зберігання продукту. При їх порушенні, особливо за підвищених температур зберігання, можуть появлятися присмаки, спричинені продуктами розпаду складових продукту. Біо- хімічні перетворення відбуваються за участі культур бактеріальної композиції або в результаті життєдіяльності залишкової або забруднюючої мікрофлори.

Дослідження показників мікробіологічної безпечності зразків йогурту проводили на початку та в кінці зберігання (табл. 3).

За вмістом патогенних мікроорганізмів впродовж усього терміну зберігання усі зразки йогурту відповідали вимогам діючого ДСТУ 4343:2004. "Йогурти. Загальні технічні умови".

Щодо кисломолочної мікрофлори, то активніший розвиток спостерігали у зразках 2,3 та 4 . Це пояснює процеси, які відбувалися під час сквашування та зберігання продукту, де спостерігали зміни показників кислотності. Кількість молочнокислих бактерій молочнокислих бактерій була найвищою і сягала на 21 добу зберігання $10^{8} \mathrm{KУO} / \mathrm{cm}^{3}$. 
У зразку 2 і 3 відзначали менший ріст і розвиток дріжджів та пліснявих грибів в порівнянні до інших зразків. Менший вміст дріжджів і плісені можливо пов'язаний із кислішим середовищем, а також бакте- рицидними властивостями штаму E. faecium SB 18, оскільки у цих зразках йогурту використано його у найбільшій кількості.

\section{Таблиця 3}

Мікробіологічні показники йогурту протягом зберігання

\begin{tabular}{ccccccc}
\hline & \multicolumn{7}{c}{ Найменування показника } \\
\cline { 2 - 8 } Дослідні зразки / доба \\
зберігання
\end{tabular}

\section{Висновки}

Як результат дослідної роботи встановлено, що склад бактеріального препарату має безпосередній вплив на формування властивостей кисломолочного продукту та на перебіг технологічного процесу.

Провівши дослідження біотехнологічних процесів, що відбуваються під час виробництва йогурту із різним складом молочнокислих бактерій, визначено, що використання традиційної йогуртової закваски YoFlex Premium 1.0 та Creamy 1.0. разом із бактеріальною культурою E. faecium SB 18 у співвідношенні 80:20, забезпечує відмінні споживні властивості продукту.

При використанні додаткової культури E. faecium SB 18 в технології йогурту "Карпатський” відзначено незначні зміни та відмінності в показниках активної та титрованої кислотності, консистенції та мікробіологічних властивостях продукту, тоді як значних відмінностей між сенсорними властивостями не було.

Позитивний влив відзначено на функціональні властивості продукту шляхом збільшення вмісту життєздатних клітин пробіотичних бактерій.

\section{References}

Akpinar, A., Saygili, D., \& Yerlikaya, O. (2020). Production of set-type yoghurt using Enterococcus faecium and Enterococcus durans strains with probiotic potential as starter adjuncts. International J. of Dairy Technology, 73(4), 726-736. doi: 10.1111/1471-0307.12714.

Andrade, J., Ascenção, K., Gullón, P., Henriques, S. M. S., Pinto, J. M. S., Rocha-Santos, T. A. P., Freitas, A C., \& Gomes, A. M. (2012). Production of conjugated linoleic acid by food-grade bacteria: A review. Int. J.
Dairy Technol., 65(4), 467-481. doi: 10.1111/j.14710307.2012.00871.x.

Andrighetto, C., Knijff, E., Lombardi, A., Torriani, S., Vancanneyt, M., Kersters, K., Swings, J., \& Dellaglio, F. (2001). Phenotypic and genetic diversity of enterococci isolated from Italian cheeses. J. Dairy Res., 68(2), 303-316. doi: 10.1017/S0022029901004800.

Andrighetto, C., Marcazzan, G., Cariolato, D., Storti, A., Cattelan, A., \& Lombardi, A. (2006). Isolation and characterization of microrganisms from traditional Triveneto cheeses. Sci. Tecn. Latt-Cas, 57309-318.

Behnsen, J., Deriu, E., Sassone-Corsi, M., \& Raffatellu, M. (2013). Probiotics: properties, examples, and specific applications. Cold Spring Harb Perspect Med, 3(3), a010074. doi: 10.1101/cshperspect.a010074.

Câmara, S. P. A., Dapkevicius, A., Riquelme, C., Elias, R. B., Silva, C. C. G., Malcata, F. X., \& Dapkevicius, M. L. N. E. (2019). Potential of lactic acid bacteria from Pico cheese for starter culture development. Food Sci. Technol. Int. 25(4), 303-317. doi: $10.1177 / 1082013218823129$.

Didukh, N. A. (2008). Naukovi osnovy rozrobky tekhnolohii molochnykh produktiv funktsionalnoho pryznachennia: avtoref. dys. na zdobuttia naukovoho stupenia d-ra tekhn. nauk: 05.18.16. Didukh Nataliia Andriivna, Odesa (in Ukrainian).

Durlu-Ozkaya, F., Xanthopoulous, V., Tunail, N., \& Litopoulou-Tzanetaki, E. (2001). Technologically important properties of lactic acid bacteria isolates from Beyaz cheese made from raw ewes' milk. J. Appl. Microbiol, 91(5), 861-870. doi: 10.1046/j.13652672.2001.01448.x.

Fortina, M. G., Ricci, G., Borgo, F., Manachini, P.L., Arends, K., Schiwon, K., Abajy, M. Y., \& Grohmann, E. (2008). A survey on biotechnological potential and 
safety of the novel Enterococcus species of dairy origin, E. italicus. Int. J. Food Microbiol, 123(3), 204211. doi: 10.1016/j.ijfoodmicro.2008.01.014.

Franz, C., Huch, M., Abriouel, H., Holzapfel, W., \& Galvez, A. (2011). Enterococci as probiotics and their implications in food safety. Int. J. Food Microbiol, 151(2), 125-140. doi: 10.1016/j.ijfoodmicro.2011.08.014.

García-Solache, M., \& Rice, L. B. (2019). The Enterococcus: A model of adaptability to its environment. Clin. Microbiol. Rev., 32, e00058-18. doi: 10.1128/CMR.00058-18.

GenBank. MZ227257. Enterococcus faecium strain SB18 $16 \mathrm{~S}$ ribosomal RNA gene, partial sequence. URL: https://www.ncbi.nlm.nih.gov/nuccore/MZ227257

Giraffa, G. (2003). Enterococci from foods. FEMS Microbiol. Rev., 26(2), 163-171. doi: 10.1111/j.15746976.2002.tb00608.x.

Graham, K., Stack, H., \& Rea, R. (2020). Safety, beneficial and technological properties of enterococci for use in functional food applications-a review. Crit. Rev. Food Sci. Nutr., 60(22), 3836-3861. doi: 10.1080/10408398.2019.1709800.

Gútiez, L., Borrero, J., Jiménez, J. J., Gómez-Sala, B., Recio, I., Cintas, L. M., Herranz, C., \& Hernández, P. E. (2014). Genetic and biochemical evidence that recombinant Enterococcus spp. strains expressing gelatinase (GelE) produce bovine milk-derived hydrolysates with high angiotensin convertingenzyme-inhibitory activity. J. Agric. Food Chem., 62(24), 5555-5564. doi: 10.1021/jf5006269.

Hadji-Sfaxi, I., El-Ghaish, S., Ahmadova, A. et al. (2018). Antimicrobial activity and safety of use of Enterococcus faecium PC4.1 isolated from Mongol yogurt. Food Control, 22(12), 2020-2027 doi: 10.1016/j.foodcont.2011.05.023.

Kishino, S., Ogawa, J., Omura, Y., Matsumura, K., \& Shimizu, S. (2002). Conjugated linoleic acid production from linoleic acid by lactic acid bacteria. J. Am. Oil Chem. Soc., 79(2), 159-163. doi: 10.1007/s11746-002-0451-4.

Kushnir, I., Tsisaryk, O., Shalovylo, S., Gutyj, B., Kushnir, G., Slyvka, I., \& Musiy, L. (2020). The ability of enterococci extracted from traditional Carpathian cheese bryndza to produce biologically active substances. Ukrainian Journal of Veterinary and Agricultural Sciences, 3(3), 15-19. doi: 10.32718/ujvas3-3.0.

Kushnir, I., Tsisaryk, O., Slyvka, I., Musiy, L., Kushnir, I., \& Semen, I. (2020). Growth intensity and antibacterial properties of Enterococcus faecium and Enterococcus durans strains isolated from traditional Carpathian brynza. Scientific Messenger of LNU of Veterinary Medicine and Biotechnologies. Series: Agricultural Sciences, 22(92), 42-49. doi: 10.32718/nvlvet-a9208.

Ljungh, A., \& Wadstrom, T. (2006). Lactic acid bacteria as probiotics. Curr Issues Intest Microbiol, 7(2), 7389. URL: https://pubmed.ncbi.nlm.nih.gov/16875422.
Marshall, V. M. (2007). Probiotics and Prebiotics: Scientific Aspects (2005). Int. J. Dairy Tech, 60(1), 63-64. doi: 10.1111/j.1471-0307.2007.00272.x.

McSweeney, P. (2004). Biochemistry of cheese ripening. Int. J. Dairy Technol 57(2-3), 127-144. doi: 10.1111/j.1471-0307.2004.00147.x.

Muguerza, B., Ramos, M., Sánchez, E., Manso, M. A., Miguel, M., Aleixandre, A., Delgado, M. A., \& Recio, I. (2006). Antihypertensive activity of milk fermented by Enterococcus faecalis strains isolated from raw milk. Int. Dairy J., 16(1), 61-69. doi: 10.1016/j.idairyj.2005.01.001.

Nascimento, L. C. S., Casarotti, S. N., Todorov, S. D., \& Penna, A. L. B. (2019). Probiotic potential and safety of enterococci strains. Ann. Microbiol, 69, 241-252. doi: 10.1007/s13213-018-1412-5.

Ozen, M., \& Dinleyici, E. (2015). The history of probiotics: the untold story. Benef Microbes, 6(2), 159-165. doi: 10.3920/BM2014.0103.

Perin, L. M., Belviso, S., Dal Bello, B., Nero, L. A., \& Cocolin, L. (2017). Technological properties and biogenic amines production by bacteriocinogenic lactococci and enterococci strains isolated from raw goat's milk. J. Food Prot, 80(1), 151-157. doi: 10.4315/0362-028X.JFP-16-267.

Quirós, A., Ramos, M., Muguerza, B., Delgado, M.A., Miguel, M., Aleixandre, A., \& Recio, I. (2007). Identification of novel antihypertensive peptides in milk fermented with Enterococcus faecalis. Int. Dairy J., 17(1), 33-41. doi: 10.1016/j.idairyj.2005.12.011.

Regazzo, A., Dalt, L., Lombardi, A., Andrighetto, C., \& Negro, A. (2010). Fermented milks from Enterococcus faecalis TH563 and Lactobacillus delbrueckii subsp. bulgaricus LA2 manifest different degrees of ACE-inhibitory and immunomodulatory activities. Dairy Science \& Technology, 90(4), 469476. doi: 10.1051/dst/2010009.

Romanchuk, I. O., Rudakova, T. V., Andreus, S. M., \& Moiseieva, L. O. (2015). Kharchova tsinnist funktsionalnoho kyslomolochnoho produktu herodiietychnoho pryznachennia. Prodovolchi resursy. Tekhnichni nauky, 4, 23-26 (in Ukrainian).

Sarantinopoulos, P., Andrighetto, C., Gerogalaki, M. D., Rea, M. C., Lombardi, A., Cogan, T. M., Kalantzopoulos, G., \& Tsakalidou, E. (2001). Biochemical properties of enterococci relevant to their technological performance. Int. Dairy J., 11(8), 621647. doi: 10.1016/S0958-6946(01)00087-5.

Serio, A., Chaves-López, C., Paparella, A., \& Suzzi, G. (2010). Evaluation of metabolic activities of enterococci isolated from Pecorino Abruzzese cheese. Int. Dairy J., 20(7), 459-464. doi: 10.1016/j.idairyj.2010.02.005.

Slyvka, I. M., Tsisaryk, O. Y., Dronyk, G. V., \& Musiy, L. Y. (2018). Strains of lactic acid bacteria isolated from traditional Carpathian cheeses. Regulatory Mechanisms in Biosystems, 9(1), 62-68. doi: 10.15421/021808. 